\title{
KOMUNIKASI PEMBERDAYAAN SEBAGAI PERSPEKTIF BARU PENGEMBANGAN PENDIDIKAN KOMUNIKASI PEMBANGUNAN DI INDONESIA
}

\author{
Empowerment Communication as a New Perspective of Education Development \\ for Development Communication in Indonesia
}

\author{
Yuli Setyowati \\ Sekolah Tinggi Pembangunan Masyarakat Desa “APMD” \\ Email: gracedista@yahoo.co.id
}

\begin{abstract}
The presence of development communication is basically aimed at contributing to the development process, especially in order to accelerate the diffusion process of innovation. The diffusion of innovation in development is an effort to meet the demands of modernization. Therefore, development is often equated with the term modernization. One indicator of modernization is the presence of communication technology that is very fast developing. Communication technology that was created to facilitate human work in the end was not able to place humans as subjects, but instead became the object of technology. The helplessness of individual humans when dealing with communication technology is a picture of the failure of the development process and human-centered social change. Communities are often powerless to stem the hegemony of communication technology. Therefore empowerment communication is a new perspective in the education of development communication in the spirit of voicing the voiceless. This study aims to reveal the social changes that occur in the "thugs" community in the development process as an illustration of community empowerment in communication seen from the perspective of the theory of communicative action. This research is a case study using a qualitative approach. Data was collected through in-depth interviews, observation, and documentation. The results of this study include: 1) Changes in people's mindsets are able to bring them to a pattern of behavior that is different from before. In the process of this change it can be seen that in the community there is a process of self-help to get out of stigma as a "village of thugs"; 2) Communicative actions of the community based on four claims according to the communicative action theory of Habermas in the empowerment process show the empowerment of the community in communicating that moves them in a living condition based on the existence of mutually agreed upon values and norms; 3) The functioning of social groups into public spaces for the community to communicate and express, thus fostering emancipation and solidarity among the community. Social groups are the most effective forum for empowerment at the community level that enables individuals to organize themselves in these groups (collective self-empowerment) so that a dialogical encounter occurs that fosters and strengthens awareness of communication and group solidarity.
\end{abstract}

Keywords: communication, empowerment, development, communicative action

\begin{abstract}
ABSTRAK
Hadirnya komunikasi pembangunan pada dasarnya ditujukan untuk memberikan kontribusi dalam proses pembangunan, terutama dalam rangka mempercepat proses difusi inovasi. Difusi inovasi dalam pembangunan ini merupakan upaya memenuhi tuntutan modernisasi. Oleh sebab itu, pembangunan seringkali disamakan dengan istilah modernisasi. Salah satu indikator modernisasi adalah hadirnya teknologi komunikasi yang sangat cepat perkembangannya. Teknologi komunikasi yang diciptakan untuk mempermudah pekerjaan manusia pada akhirnya tidak mampu menempatkan manusia sebagai subjek, namun justru menjadi objek teknologi. Ketidakberdayaan individu
\end{abstract}


manusia ketika berhadapan dengan teknologi komunikasi merupakan gambaran dari gagalnya proses pembangunan dan perubahan sosial yang berpusat pada manusia. Masyarakat seringkali tidak berdaya membendung hegemoni teknologi komunikasi. Oleh sebab itu komunikasi pemberdayaan menjadi perspektif baru dalam pendidikan komunikasi pembangunan dengan semangat voicing the voiceless. Penelitian ini bertujuan mengungkap perubahan sosial yang terjadi pada masyarakat "kampung preman" dalam proses pembangunan sebagai gambaran keberdayaan masyarakat dalam berkomunikasi dilihat dari perspektif teori tindakan komunikatif. Penelitian ini merupakan studi kasus dengan menggunakan pendekatan kualitatif. Data dikumpulkan melalui wawancara mendalam, observasi, dan dokumentasi. Hasil dari penelitian ini meliputi: 1) Perubahan pola pikir masyarakat mampu membawa mereka pada pola perilaku yang berbeda dengan sebelumnya. Dalam proses perubahan ini dapat dilihat bahwa pada masyarakat terjadi proses self-help (menolong diri sendiri) untuk keluar dari stigma sebagai "kampung preman"; 2) Tindakan komunikatif masyarakat berdasarkan empat klaim menurut teori tindakan komunikatif dari Habermas dalam proses pemberdayaan memperlihatkan keberdayaan masyarakat dalam berkomunikasi yang menggerakkan mereka pada suatu kondisi kehidupan yang didasari oleh adanya nilai-nilai dan norma-norma yang disepakati bersama; 3) Berfungsinya kelompok-kelompok sosial menjadi ruang-ruang publik bagi masyarakat untuk berkomunikasi dan berekspresi, sehingga menumbuhkan emansipasi dan solidaritas di kalangan masyarakat. Kelompok sosial sebagai wadah paling efektif untuk pemberdayaan di tingkat komunitas yang memampukan individu untuk mengorganisir diri dalam kelompok tersebut (collective self-empowerment) sehingga terjadi suatu dialogical encounter (pertemuan dialogis) yang menumbuhkan dan memperkuat kesadaran berkomunikasi dan solidaritas kelompok.

Kata kunci: komunikasi, pemberdayaan, pembangunan, tindakan komunikatif

\section{PENDAHULUAN}

Kemunculan paradigma baru komunikasi pembangunan ditandai dengan adanya kesadaran bahwa proses komunikasi dalam pembangunan harus berpedoman pada kemampuan masyarakat dalam merencanakan, melaksanakan, dan mengevaluasi pembangunan. Dalam hal ini masyarakat bukanlah objek pembangunan, melainkan subjek pembangunan, oleh sebab itu partisipasi masyarakat merupakan faktor yang sangat penting. Komunikasi dilaksanakan secara konvergen, interaksi komunikasi dilakukan secara lebih demokratis dan partisipatif. Kegiatan komunikasi bukan kegiatan memberi dan menerima melainkan "berbagi" dan "berdialog." Selama ini, keterlibatan masyarakat hanya dilihat dalam konteks yang sempit, artinya masyarakat hanya dipandang sebagai pihak penerima inovasi pembangunan semata, tanpa dilibatkan dalam perencanaan dan pengambilan keputusan dan tidak dikembangkan daya kreatif dari dalam dirinya dan harus menerima keputusan yang sudah diambil pihak luar dirinya. Akibatnya tercipta ketergantungan masyarakat pada pihak lain, tidak berdaya dan mandiri.

Pemberdayaan masyarakat merupakan paradigma alernatif pembangunan dengan tujuan membawa masyarakat kepada keberdayaan dan kemandirian. Untuk menuju pada kemandirian masyarakat, upaya pencapaian kesejahteraan menjadi hal yang utama. Masyarakat yang sejahtera akan mampu mengatasi kebutuhan hidupnya, baik kebutuhan materiil maupun non-materiil seperti dinyatakan oleh Mardikanto (2010) bahwa tujuan pembangunan adalah perubahan yang menyeluruh mencakup beragam aspek dan tatanan kehidupan masyarakat yang bersangkutan, baik materiil maupun non-materiil. Esensi setiap kegiatan pembangunan adalah terjadinya perubahan sikap untuk memproyeksikan diri ke 
dalam situasi lain dan arena itu secara sadar dan terencana menyiapkan diri untuk melakukan perubahan-perubahan untuk memperbaiki mutu hidupnya guna mengantisipasi keadaan dan perubahan-perubahan yang akan terjadi di masa mendatang. Dari tujuan di atas, pembangunan yang baik adalah pembangunan yang berbasis masyarakat itu sendiri menuju pada kondisi perbaikan mutu hidup yang diharapkan.

Adapun pemberdayaan masyarakat merupakan kegiatan yang memerlukan proses berkelanjutan, maka dibutuhkan komunikasi yang baik antara inisiator program dengan masyarakat maupun antar warga masyarakat. Proses pemberdayaan tersebut tidak akan mencapai tujuannya, jika tidak didukung oleh proses komunikasi yang partisipatif. Dalam hal ini dibutuhkan partisipasi aktif dari seluruh warga masyarakat untuk mewujudkan cita-cita perubahan yang diinginkan. Partisipasi masyarakat sangat berpengaruh terhadap terbentuknya tindakan komunikatif yang sesuai dengan karakteristik masyarakatnya. Resistansi masyarakat dalam proses pemberdayaan masih sering muncul karena perasaan saling curiga diantara komponen masyarakat tentang kepentingankepentingan di balik upaya pemberdayaan, terutama dari kelompok masyarakat yang tidak menjadi sasaran utama program pemberdayaan tersebut. Walaupun resistansi terhadap upaya-upaya pemberdayaan untuk membawa pada perubahan masyarakat cukup tinggi, komunikasi memainkan peran yang sangat penting dalam terbentuknya tindakan komunikatif masyarakat.

Hadirnya komunikasi pembangunan pada dasarnya ditujukan untuk memberikan kontribusi dalam proses pembangunan, terutama dalam rangka mempercepat proses difusi inovasi. Difusi inovasi dalam pembangunan ini merupakan upaya memenuhi tuntutan modernisasi. Oleh sebab itu, pembangunan seringkali disamakan dengan istilah modernisasi. Salah satu indikator modernisasi adalah hadirnya teknologi komunikasi yang sangat cepat perkembangannya. Teknologi komunikasi yang diciptakan untuk mempermudah pekerjaan manusia pada akhirnya tidak mampu menempatkan manusia sebagai subjek, namun justru menjadi objek teknologi. Ketidakberdayaan individu manusia ketika berhadapan dengan teknologi komunikasi merupakan gambaran dari gagalnya proses pembangunan dan perubahan sosial yang berpusat pada manusia. Masyarakat seringkali tidak berdaya membendung hegemoni teknologi komunikasi. Oleh sebab itu komunikasi pemberdayaan menjadi perspektif baru dalam pendidikan komunikasi pembangunan dengan semangat voicing the voiceless. Penelitian ini bertujuan mengungkap perubahan sosial yang terjadi pada masyarakat "kampung preman" dalam proses pembangunan sebagai gambaran keberdayaan masyarakat dalam berkomunikasi dilihat dari perspektif teori tindakan komunikatif.

Kampung Badran merupakan sebuah wilayah di kota Yogyakarta yang dahulu terkenal dengan stigma "kampung preman". Masyarakat yang hidup dengan stigma "kampung preman" sering dipersepsi sebagai tipe masyarakat yang sulit berubah. Hal ini disebabkan oleh adanya berbagai permasalahan yang dianggap tidak lazim oleh masyarakat lain. Adanya perilaku-perilaku masyarakat yang bersifat negatif, seperti perilaku kekerasan dan kriminal membuat kehidupan masyarakat menjadi terganggu. Namun demikian, persepsi tersebut tidaklah selalu benar. Beberapa dekade yang lalu masyarakatnya sempat mengalami kondisi yang cukup memprihatinkan dan menakutkan. Namun kondisi tersebut telah mengalami perubahan yang signifikan sekitar 15 tahun terakhir. Hal ini terjadi karena adanya 
upaya perubahan dengan melakukan pemberdayaan masyarakat yang diinisiasi oleh para tokoh masyarakat.

Perubahan masyarakat "kampung preman" dapat dilihat dari tindakan komunikatif masyarakat yang semula hidup dalam kondisi yang sering diwarnai oleh kekerasan dan konflik menjadi bertolak belakang dengan tipologi masyarakat komunikatif yang ditandai dengan relasi yang setara dan harmoni. Dengan tindakan komunikatifnya, masyarakat mengalami perubahan demi perubahan. Oleh sebab itu, kajian tentang pemberdayaan masyarakat yang dilihat dari tindakan komunikatif ini menjadi menarik mengingat histori dan karakteristik masyarakat "kampung preman" tersebut di atas.

\section{TINJAUAN PUSTAKA}

Ife (2008) menyatakan bahwa pembangunan pada dasarnya adalah membangkitkan sumber daya manusia, kesempatan, pengetahuan, dan keterampilan untuk meningkatkan kapasitas dalam menentukan masa depan. Definisi ini berangkat dari konsep utama yaitu memberikan kesempatan yang luas bagi masyarakat untuk menentukan sendiri arah kehidupan dalam komunitasnya.

Menurut Chambers (1995), pemberdayaan masyarakat adalah sebuah konsep pembangunan ekonomi yang merangkum nilai-nilai sosial yang mencerminkan paradigma baru pembangunan, yakni yang bersifat "people centered development, participatory, empowering, and sustainable”. Konsep ini berkembang dari beberapa pemikiran tentang alternative development, salah satunya adalah pemikiran Friedman, yang menghendaki adanya 'inclusive democracy, appropriate economic growth, gender equity and intergenerational equity".

Berangkat dari tujuan pengembangan masyarakat untuk membangkitkan sumber daya manusia, maka inti dari pengembangan masyarakat adalah mendidik, membuat anggota masyarakat mampu mengerjakan sesuatu dengan memberikan kekuatan atau sarana yang diperlukan untuk memberdayakan mereka. Untuk itu dibutuhkan nilai-nilai keterbukaan, persamaan, pertanggungjawaban, kesempatan, pilihan, pertisipasi, saling menguntungkan, saling timbal balik, dan pembelajaran terus-menerus (FCDL dalam Zubaedi, 2014).

Tahoba (2011), menyatakan bahwa keterlibatan masyarakat dalam program community development membawa dampak pada perbedaan komunikasi antara masyarakat yang berpartisipasi dengan masyarakat yang tidak berpartisipasi.Masyarakat yang berpartisipasi lebih mengalami perubahan pengetahuan, keterampilan dan sikap akibat penyampaian pesan atau inovasi yang ditawarkan dibanding dengan masyarakat yang tidak berpartisipasi.Masyarakat yang tidak berpartisipasi cenderung menunjukkan sikap acuh tak acuh atau malas mencari tahu tentang pesan yang disampaikan.

Tindakan komunikatif menurut Habermas (1984) mengacu pada tindakan yang diarahkan oleh norma-norma yang disepakati bersama berdasarkan harapan timbal balik diantara subjek-subjek yang berinteraksi dengan menggunakan simbol-simbol, khususnya bahasa sehari hari sebagai medium bagi tindakan tersebut. Komunikasi menjadi titik tolak dalam teori ini, dan praksis menjadi konsep sentralnya. Praksis bukan diartikan sebagai tingkah laku buta berdasarkan naluri belaka, melainkan tindakan dasar manusia sebagai makhluk sosial yang diterangi oleh kesadaran rasional. Rasio tidak hanya tampak dalam kegiatan 
menaklukkan alam melalui kerja, melainkan juga dalam interaksi intersubjektif yang menggunakan bahasa sehari-hari.

Dalam Teori Tindakan Komunikatif terdapat empat klaim, yaitu: (1) klaim kebenaran (truth) yaitu kesepakatan tentang dunia alamiah dan objektif ; (2) klaim ketepatan (rightness) yaitu kesepakatan tentang pelaksanaan norma-norma dalam dunia sosial; (3) klaim autentisitas/kejujuran (sincerity) yaitu kesepakatan tentang kesesuaian antara dunia batiniah dan ekspresi seseorang; dan (4) klaim komprehensibilitas (comprehensibility) yaitu kemampuan menjelaskan klaimklaim di atas dan mencapai kesepakatan atasnya. Setiap komunikasi yang efektif harus mencapai klaim keempat dan orang yang mampu berkomunikasi dalam arti menghasilkan klaim-klaim tersebut memiliki "kompetensi komunikasi" (Hardiman, 2009).

\section{METODE PENELITIAN}

Berdasarkan permasalahan yang diteliti, jenis penelitian ini adalah kualitatif deskripstif. Penelitian kuatitatif deskriptif merupakan penelitian yang mampu menangkap berbagai informasi kualitatif dengan deskripsi teliti dan penuh nuansa (Soetopo, 2006), untuk memahami fenomena yang dialami subjek penelitian seperti perilaku, persepsi, motivasi, tindakan secara holistik, dengan cara deskripsi dalam bentuk kata-kata dan bahasa, pada suatu konteks khusus yang alamiah dan dengan memanfaatkan berbagai metode ilmiah(Moleong, 2004).

Strategi penelitian yang digunakan adalah studi kasus tunggal, sebab penelitian ini terarah pada sasaran dengan satu karakteristik yang berada di satu lokasi (Yin, 1987). Creswell (1998) menyatakan bahwa fokus studi kasus adalah spesifikasi kasus dalam suatu kejadian, baik yang mencakup individu, kelompok budaya ataupun suatu potret kehidupan. Jenis strategi penelitian kasus ini juga dapat disebut studi kasus terpancang (embedded case study) research, karena permasalahan dan fokus penelitian sudah ditentukan sejak awal (Soetopo, 2006).

Pengumpulan data dilakukan dengan menggunakan wawancara mendalam, observasi, focus group discussion (FGD), dan dokumentasi. Informan dipilih dengan menggunakan teknik purposive dan snowball sampling. Purposive sampling digunakan untuk memilih informan yang dipandang memiliki kecukupan informasi berdasarkan tujuan penelitian, sedang snowball sampling digunakan untuk mencari data dari informan yang tidak dapat ditentukan sejak awal penelitian.

Data yang diperoleh dianalisis dengan menggunakan model analisis interaktif. Menurut Miles dan Haberman (1984) model analisis ini terdiri dari tiga komponen analisis yaitu: reduksi data, sajian data, dan penarikan simpulan. Aktivitas atas tiga komponen tersebut dilakukan dalam bentuk interaktif dengan proses pengumpulan data sebagai suatu proses siklus. Data divalidasi dengan mengunakan triangulasi sumber dan metode.

\section{HASIL DAN PEMBAHASAN}

\section{Perubahan pola pikir dan pola perilaku masyarakat}

Perubahan pola pikir masyarakat mampu membawa mereka pada pola perilaku yang berbeda dengan sebelumnya. Dalam proses perubahan ini dapat dilihat bahwa pada masyarakat terjadi proses self-help (menolong diri sendiri) 
untuk keluar dari stigma sebagai "kampung preman". Robbins, Chatterjee \& Canda (Mardikanto, 2010), menyatakan bahwa pemberdayaan masyarakat adalah: "process by which individuals and groups gain power, acces to resources and control over their own lives. In doing so, they gain the ability to achieve their highest personal and collective aspirations and goals". Pemberdayaan masyarakat merupakan proses dimana individu-individu dan kelompok-kelompok memiliki kekuatan, kesempatan mengakses sumber daya yang ada dan mengontrol kehidupan mereka sendiri.

Proses perubahan yang terjadi di Kampung Badran sangat didukung dengan adanya tindakan komunikatif masyarakat berdasarkan pada norma, nilai dan simbol-simbol yang disepakati bersama. Kebiasaan-kebiasaan buruk yang dulu banyak dilakukan oleh masyarakat yang ditandai dengan berlakunya norma, nilai dan simbol-simbol yang digunakan kini telah mengalami perubahan yang drastis. Sebagai contoh kebiasaan judi dan minum yang dulu selalu dilakukan pada setiap hajatan, sekarang sudah hampir hilang. Hal ini diceritakan oleh Ibu Azizah (49 tahun) demikian,

"Yaa...kalau dibilang sekarang Badran ini sudah berubah, 80\% warga yang dulu punya kebiasaan minum, judi dan teman-temannya itu sudah berubah, kalau dulu dianggap hitam sekarang sudah menjadi putih. Yang 20\%nya sudah tidak hitam lagi tapi sudah jadi abu-abu" (Wawancara tanggal 29 Juli 2016).

Sebuah upaya pemberdayaan masyarakat dapat berjalan dengan baik karena ada semangat dari masyarakat, didukung dengan adanya dorongan atau dukungan dari para tokoh masyarakat dan para pemimpin formal. Persoalan uang bukanlah menjadimasalah utama dalam proses pemberdayan masyarakat. Hal ini ditegaskan oleh Bapak Sisruwadi (55 tahun), mantan Camat Kecamatan Jetis periode tahun 2007-2012,

“jika masyarakat semangat, tetapi tidak ada dukungan, maka pemberdayaan masyarakat tidak akan jalan, tetapi walaupun semangat masyarakat itu kecil, jika ada dorongan, maka hasilnya bagus. Masyarakat akan mudah digerakkan, urunan duit(iuran uang) sudah gak masalah.Lebih sulit menggerakkan daripada mendorong.Jadi harus pandai-pandai mencermati karakter masyarakat" (Wawancara tanggal 15 September 2016).

Dalam hal ini dibutuhkan sebuah cara berkomunikasi yang mampu membangkitkan daya dorong masyarakat untuk bergerak menuju pada cita-cita perubahan yang diinginkan bersama. Komunikasi inilah yang dikembangkan oleh para tokoh masyarakat dan para pemimpin formal di wilayah "kampung preman", yaitu berkomunikasi dengan menggunakan bahasa yang mudah dipahami oleh masyarakat dan sesuai dengan karakter mereka. Dari cara berkomunikasi yang memberdayakan dan bersifat partisipatif, berdampak pada perubahan pola pikir masyarakat.

Melalui komunikasi pemberdayaan di "kampung preman", masyarakat mempunyai kemampuan untuk mencapai aspirasi dan tujuan-tujuan yang lebih tinggi, baik personal maupun kelompok. Terbukti dengan adanya responsivitas masyarakat yang tinggi terhadap perubahan. Sikap responsif tersebut sangat didukung oleh adanya kesukaan belajar yang tinggi. Setiap informasi baru selalu 
dapat ditransfer secara efektif mulai dari pemangku wilayah kepada kelompokkelompok kegiatan dan diteruskan sampai ke setiap keluarga.

Ketika pola pikir dan perilaku masyarakat sudah berubah, akan menghasilkan struktur masyarakat yang berubah juga. Struktur masyarakat yang baru diwarnai dengan adanya nilai-nilai baru. Dalam konteks masyarakat Kampung Badran, nilai-nilai baru tersebut berkaitan dengan aspek pendidikan, kesehatan, dan ekonomi keluarga yang manfaatnya langsung bisa dirasakan oleh keluarga secara khusus, dan dalam lingkup yang lebih luas manfaat tersebut dapat dirasakan oleh masyarakat. Hal tersebut secara otomatis dapat mempengaruhi dunia batiniah masyarakat dan akan terekspresikan dalam tindakan sehari-hari. Di sinilah dapat dilihat adanya klaim autentisitas/kejujuran (sincerity).

\section{Tindakan komunikatif masyarakat}

Tindakan komunikatif masyarakat "kampung preman" dapat dilihat dari empat klaim menurut teori tindakan komunikatif dari Habermas dalam proses pemberdayaan. Dalam tindakan komunikatif mereka, memperlihatkan adanya keberdayaan masyarakat dalam berkomunikasi yang mampu menggerakkan mereka pada suatu kondisi kehidupan yang didasari oleh adanya nilai-nilai dan norma-norma yang disepakati bersama.

Bentuk komunikasi yang dominan terjadi dalam dinamika partisipasi warga Kampung Badran adalah komunikasi interpersonal. Ketika kegiatan belum dimulai, situasi komunikasi diantara mereka merupakan komunikasi yang santai dan akrab. Partisipasi aktif warga dalam situasi formal mencerminkan bahwa mereka adalah warga yang sangat menghormati forum. Warga sangat paham di saat kapan mereka bisa berkomunikasi secara santai dan guyon dan di saat kapan mereka harus serius tapi santai. Informasi yang didapat pada pertemuan level RW akan diteruskan ke pertemuan-pertemuan di kelompok-kelompok pada level RT dan dasa wisma.Dalam kegiatan-kegiatan tersebut, kaum perempuan banyak mengambil peran secara aktif.

Dengan cara seperti ini, dapat dikatakan bahwa warga Kampung Badran adalah warga yang well informed, mereka hampir tidak pernah ketinggalan informasi seputar perkembangan dan aktivitas yang harus mereka ketahui dan ikuti. Penggunaan alat komunikasi saat ini menjadi sangat penting sebagai media komunikasi antarindividu dan kelompok.

Pengaruh komunikasi dalam kelompok-kelompok sosial di Kampung Badran terhadap perubahan-perubahan perilaku masyarakatnya cukup besar. Dari hasil wawancara dan observasi dapat dilihat bahwa respon masyarakat untuk terlibat dalam kelompok-kelompok sosial tersebut sangat tinggi. Satu individu dapat tergabung dalam 4 atau 5 atau lebih kelompok sosial. Mereka sangat menikmati aktivitas kelompok-kelompok yang diikuti. Dengan demikian, interaksi yang terjadi di dalam kelompok sangat mempengaruhi perilaku anggota kelompoknya.

Dalam proses waktu, perubahan karakter masyarakat Badran yang dulu hidup dengan stigma "kampung preman" mengalami dinamika dalam tindakan komunikasinya. Bentuk komunikasi yang digunakan lebih banyak menggunakan komunikasi interpersonal. Meskipun masyakakat Badran termasuk dalam wilayah perkotaan, namun sifat-sifat tindakan komunikasinya lebih mencerminkan tindak komunikasi yang menjunjung tinggi rasa kekeluargaan, solidaritas dan rasa 
empati. Bahasa sehari-hari sebagai simbol berkomunikasi saat ini merupakan bahasa yang lebih beretika, artinya bahasa yang tidak mengandung kekerasan dan dapat membangun harmoni kehidupan masyarakat. Seperti pendapat Habermas (Hardiman, 2009), bahwa tindakan komunikatif diarahkan oleh norma-norma yang disepakati bersama berdasarkan harapan timbal balik diantara subjek-subjek yang berinteraksi dengan menggunakan simbol-simbol, khususnya bahasa sehari hari sebagai medium bagi tindakan tersebut. Dalam hal ini bahasa dalam komunikasi menjadi unsur yang sangat penting untuk menghasilkan tindakan komunikatif tertentu. Tindakan komunikatif ini muncul sebagai hasil interaksi antarsubjek sesuai dengan kesepakatan di antara subjek tersebut.

Sulaiman (2013) dalam penelitiannya di desa Pasuruhan, kecamatan Binangun,Cilacap yang berjudul "Model Komunikasi Formal dan Informal dalam Proses Kegiatan Pemberdayaan Masyarakat" memperlihatkan hasil bahwa komunikasi formal tidak bisa dipisahkan dari komunikasi informal dalam proses penelitian dan pelaksanaan pemberdayaan. Komunikasi formal dilakukan setelah akses terbuka dan untuk mempertegas suatu tujuan kegiatan. Kegagalan proses komunikasi informal mengakibatkan resistansi, kurang mendapatkan dukungan, timbul kecurigaan, bahkan bisa terjadi penolakan dari informan penelitian. Komunikasi formal memiliki sifat terstruktur, terfokus, dan adanya interaksi simbol atas nama status institusi atau lembaga dari para pelaku komunikasi. Sedangkan komunikasi informal sifatnya tidak terstruktur, proses dialog lebih bebas atau tidak kaku yang bisa berlangsung lama, walaupun pembahasan bisa saja tidak fokus. Interaksi mengutamakan keakraban atau menjalin hubungan yang intens.

Dalam kaitannya dengan proses sosial, komunikasi menjadi sebuah cara dalam melakukan perubahan sosial (social change). Komunikasi berperan menjembatani perbedaan dalam masyarakat karena mampu merekatkan kembali sistem sosial masyarakat dalam usahanya melakukan perubahan. Dalam hal ini, komunikasi tak akan lepas dari konteks sosialnya, artinya proses komunikasi akan diwarnai oleh sikap, perilaku, pola, norma, dan pranata masyarakatnya (Nurudin, 2004).

Peran komunikasi dalam masyarakat dikemukakan secara lebih khusus oleh Dewey (Mulyana, 2002), bahwa masyarakat eksis melalui komunikasi, perspektif yang sama, budaya yang sama, muncul melalui partisipasi dalam saluran komunikasi yang sama. Melalui partisipasi sosial perspektif bersama dalam kelompok diinternalisasikan dan berbagai pandangan muncul melalui kontak dan asosiasi yang berbeda. Melalui interaksi atau komunikasi orang-orang dapat bertukar makna, nilai dan pengalaman dengan menggunakan simbol dan tanda.

Dalam setiap proses komunikasi yang terjadi dalam kelompok-kelompok sosial maupun dalam komunikasi antarindividu sehari-hari, setiap individu dapat menjadi subjek bagi dirinya sendiri. Masing-masing individu bebas untuk menafsirkan setiap pesan atau informasi yang dikomunikasikan dengan individu yang lain. Proses menafsirkan tindakannya sendiri mencerminkan bahwa individu adalah subjek bagi diri dan dunianya. Tiap individu memiliki kemampuan untuk membangun atau mengonstruksi realitas sosialnya. Dalam teori Konstruksi Sosial, Peter L. Berger dan Thomas Luckman menjelaskan bahwa realitas sosial merupakan konstruksi sosial yang diciptakan oleh individu. Individu adalah manusia yang bebas melakukan hubungan antarmanusia dan menjadi penentu dalam dunia sosial yang dikonstruksi berdasarkan kehendaknya. Individu 
bukanlah korban fakta sosial, melainkan sebagai media produksi sekaligus reproduksi yang kreatif dalam mengonstruksi dunia sosialnya (Basrowi dan Sukidin, 2002).

Konsep konstruksi sosial realitas (social construction of reality) didefinisikan sebagai proses sosial melalui tindakan dan interaksi dimana individu menciptakan secara terus-menerus suatu realitas yang dimiliki dan dialami bersama secara subjektif (Poloma, 2004). Dari hasil penelitian, fenomena tersebut tertangkap dengan jelas ketika masyarakat terlibat dalam pertemuan-pertemuan kelompok. Pertemuan-pertemuan yang diadakan menjadi realitas bersama yang sangat dinamis karena masing-masing individu bebas menyampaikan pendapatnya berdasarkan cara pandangnya masing-masing. Warga masyarakat sudah terbiasa memposisikan diri, di saat ada dalam forum formal mereka akan berperilaku dan berpendapat secara formal, sedangkan di saat mereka berada dalam pertemuan yang tidak formal, perilaku dan cara bertutur kata juga menjadi santai tanpa ada sekat yang menghalangi mereka untuk berkomunikasi walaupun status sosial dan ekonomi mereka berbeda. Komunikasi mereka bersifat egaliter. Hal tersebut sepertinya tidak lepas dari latar belakang kehidupan mereka selama ini. Cara berbicara yang ceplas-ceplos menjadi ciri khas warga masyarakat Kampung Badran.

\section{Berfungsinya kelompok-kelompok sosial menjadi ruang-ruang publik bagi masyarakat}

Kelompok-kelompok sosial merupakan wadah masyarakat untuk berkomunikasi dan berekspresi, sehingga menumbuhkan emansipasi dan solidaritas di kalangan masyarakat. Kelompok sosial sebagai wadah paling efektif untuk pemberdayaan di tingkat komunitas yang memampukan individu untuk mengorganisir diri dalam kelompok tersebut (collective self-empowerment) sehingga terjadi suatu dialogical encounter (pertemuan dialogis) yang menumbuhkan dan memperkuat kesadaran berkomunikasi dan solidaritas kelompok.

Untuk memahami tindakan komunikatif masyarakat dewasa ini, maka diperlukan pemahaman tentang konsep "ruang publik". "Ruang publik" merupakan sebuah konsep yang dewasa ini menjadi populer di dalam ilmu-ilmu sosial, teori-teori demokrasi dan diskursus lainnya. Konsep ini berbicara tentang demokrasi dalam masyarakat kompleks di era globalisasi. Habermas (2015) menegaskan bahwa ruang publik memberikan peran yang penting dalam proses demokrasi. Ruang publik merupakan ruang demokratis atau wahana diskursus masyarakat, yang mana warga negara dapat menyatakan opini-opini, kepentingankepentingan dan kebutuhan-kebutuhan mereka secara diskursif. Ruang publik harus bersifat otonom, tanpa intervensi dari pemerintah. Ruang publik merupakan sarana warga berkomunikasi, berdiskusi, berargumen, dan menyatakan sikap terhadap segala problematika.

Proses pemberdayaan yang terjadi di Kampung Badran ditandai oleh banyaknya kelompok kegiatan yang mampumendorong warganya pada berbagai aktivitas yang sangat padat. Seperti paparan terdahulu pada bab ini, sampai saat ini tercatat sekitar 20 kelompok sosial pada level Rukun Warga (RW) dan semuanya tergolong aktif.Walaupun demikian, yang terlihat adalah adanya semangat yang sangat tinggi warga Kampung Badran untuk berpartisipasi dalam kelompok-kelompok kegiatan tersebut.Hal ini terlihat dari tingkat kehadiran yang 
tinggi dan adanya partisipasi aktif warga dalam mengikuti kegiatan.Terkadang dalam satu hari terdapat 2 atau lebih kegiatan yang harus diikuti oleh warga.Hal ini tidak menjadi penghalang untuk tidak berpartisipasi.Para pengurus kelompokkelompok kegiatan juga terlihat sangat bertanggung jawab.Mereka bukanlah para pengangguran, melainkan orang yang bekerja, ada yang karyawan swasta, pedagang, wirausaha rumahan, guru, dan bahkan beberapa dintaranya adalah PNS.Membaurnya warga dari berbagai status sosial ekonomi menjadikan partisipasi menjadi dinamis.Walaupun tidak dipungkiri kadang masih dirasakan ada kesenjangan, namun hal tersebut tidak menjadi penghalang utama untuk mereka berpartisipasi secara aktif. Lambat laun perbedaan dan kesenjangan tersebut dapat mereka atasi dengan cara orang yang berstatus sosial ekonomi lebih tinggi mau merangkul warga lain yang berstatus sosial ekonomi lebih rendah.

Kepengurusan kelompok-kelompok sosial yang ada di Kampung Badran mayoritas didominasi oleh perempuan. Demikian pula dengan kepengurusan di tingkat RT dan RW, perbandingan pengurus laki-laki dan perempuan adalah 2:3. Hal ini memperlihatkan bahwa perempuan di Kampung Badran memiliki kekuatan dan peran yang besar dalam proses dan dinamika masyarakat sehingga menghasilkan suatu perubahan sesuai dengan yang diharapkan.

Dalam hal ini dapat dipahami bahwa setiap masyarakat memiliki kekuatan sosial yang disebut modal sosial. Coleman (Filed, 2010) menyatakan bahwa modal sosial tidak terbatas pada golongan yang kuat, namun juga mencakup manfaat riil yang bagi golongan miskin dan terpinggirkan. Modal sosial merupakan representasi sumber daya yang melibatkan harapan akan resiprositas dan mampu melampaui individu manapun sehingga mampu membentuk jaringan yang lebih luas. Dalam jaringan tersebut, terdapat hubungan-hubungan yang diatur oleh tingginya tingkat kepercayaan dan nilai-nilai bersama.

Keberadaan kelompok-kelompok sosial yang semakin fungsional dan didorong oleh adanya pola kepemimpinan partisipatif tersebut ditandai oleh responsivitas masyarakat semakin tinggi, kemauan belajar masyarakat semakin tinggi, dan pada akhirnya masyarakat memiliki sense of belonging (rasa memiliki atau handarbeni) dan sense of accountabitilty(rasa tanggungjawab) terhadap kampungnya. Dengan kondisi demikian, muncul tindakan komunikatif masyarakat yang membawa mereka pada kebersamaan menuju pada kehidupan yang lebih baik. Tindakan komunikatif masyarakat ini muncul akibat dari terbangunnya kesadaran masyarakat mengenai kondisi kehidupan mereka selama ini, yang pada akhirnya berdampak pada perubahan karakter masyarakat. Proses komunikasi yang terjadi dalam relasi antarwarga berlangsung secara dialogis sehingga mampu menciptakan suasana yang lebih harmonis dan mendorong masyarakat untuk berubah.

Perubahan perilaku dan tindakan komunikatif masyarakat yang terjadi di Kampung Badran semakin lama semakin mengarah pada kemandirian dan kreativitas masyarakat. Tindakan komunikatif masyarakat mencerminkan adanya peningkatan kemampuan masyarakat dalam berkomunikasi, baik antarindividu, individu dengan kelompok, dan antarkelompok. Dengan adanya peningkatan kemampuan berkomunikasi, masyarakat menjadi terbiasa berjejaring sehingga semakin mandiri dan kreatif. Inilah yang disebut sebagai komunikasi pemberdayaan, suatu proses komunikasi yang memanusiakan manusia, partisipatif dan menyuarakan pihak-pihak yang selama ini tak mampu bersuara (voicing the voiceless). 
Fenomena perubahan masyarakat "kampung preman" menunjukkan bahwa komunikasi pemberdayaan saat ini menjadi perspektif baru dalam pemahaman tentang komunikasi pembangunan. Inisiasi dan partisipasi masyarakat menjadi penciri terjadinya proses komunikasi pemberdayaan dalam proses pembangunan yang mengantarkan masyarakat pada suatu kondisi mutu hidup yang lebih baik. Dalam komunikasi pemberdayaan, keberadaan teknologi ditempatkan sebagai bagian dari proses belajar masyarakat, bukan faktor penentu perubahan sosial. Seperti dikatakan oleh Habermas (Hardiman, 2009), bahwa teknologi dan faktor objektif lain baru bisa mengubah masyarakat jika masyarakat mengintegrasikannya ke dalam tindakan komunikatif yang memiliki logikanya sendiri-sendiri.

Komunikasi pemberdayaan seperti itu merupakan proses komunikasi partisipatoris (Mulyana, 2007). Model komunikasinya bersifat konvergen, yang berarti berusaha menuju pengertian yang bersifat timbal balik diantara partisipan komunikasi dalam perhatian, pengertian dan kebutuhan.Pendekatan komunikasi konvergen ini sangat efektif dalam perencanaan pembangunan yang berbasis masyarakat. Di samping itu, pendekatan ini akan meretas jalan tumbuhnya kreativitas dan kompetensi masyarakat dalam mengkomunikasikan gagasannya.

\section{KESIMPULAN DAN SARAN}

Komunikasi pemberdayaan merupakan perspektif baru dalam pendidikan komunikasi pembangunan dapat terlihat dari studi kasus perubahan masyarakat "kampung preman". Perubahan pola pikir masyarakat "kampung preman" berdampak pada perubahan pola perilaku. Dalam proses perubahan ini dapat dilihat bahwa pada masyarakat terjadi proses self-help (menolong diri sendiri) untuk keluar dari stigma sebagai "kampung preman". Tindakan komunikatif masyarakat dalam proses pemberdayaan memperlihatkan keberdayaan masyarakat dalam berkomunikasi yang menggerakkan mereka pada suatu kondisi kehidupan yang didasari oleh adanya nilai-nilai dan norma-norma yang disepakati bersama di tengah-tengah perkembangan teknologi yang semakin canggih.

Berfungsinya kelompok-kelompok sosial menjadi ruang-ruang publik bagi masyarakat untuk berkomunikasi dan berekspresi, sehingga menumbuhkan emansipasi dan solidaritas di kalangan masyarakat. Kelompok sosial sebagai wadah paling efektif untuk pemberdayaan di tingkat komunitas yang memampukan individu untuk mengorganisir diri dalam kelompok tersebut (collective self-empowerment) sehingga terjadi suatu dialogical encounter (pertemuan dialogis) yang menumbuhkan dan memperkuat kesadaran berkomunikasi dan solidaritas kelompok. Masyarakat menjadi pihak yang aktif dalam menggunakan teknologi sebagai bagian dalam proses belajar dan diinternalisasikan dalam tindakan komunikatif mereka.

\section{DAFTAR PUSTAKA}

Basrowi dan Sukidin. 2002. Metode Penelitian Perspektif Mikro: Grounded Theory, Fenomenologi, Etnometodologi, Etnografi, Dramaturgi, Interaksi Simbolik, Hermeneutic, Konstruksi Sosial, Analisis Wacana, dan Metodologi Reflektif. Surabaya: Insan Cendekia.

Chambers, R. 1995. Poverty and Livelihoods: From Impoverishment to Empowerment. New York: New York University Press. 
Field, John. 2010. Modal Sosial. Diterjemahkan oleh Nurhadi dari buku asli Social Capital (2003). Bantul DIY: Kreasi Wacana.

Habermas, Jurgen. 2015. Ruang Publik. Sebuah Kajian Tentang Kategori Masyarakat Borjuis. Penerjemah: Yudi Santoso dari judul asli The Structural Transformation of the Public Sphere: An Inquiry into a Category of Bourgeois Society. Bantul: Kreasi Wacana.

Habermas, Jurgen. 1984. The Theory of Communicative Action. Jilid 1. Boston: Beacon Press.

Hardiman, F. Budi. 2009. Menuju Masyarakat Komunikatif. Yogyakarta: Penerbit Kanisius.

Hardiman, F. Budi (editor). 2010. Ruang Publik. Yogyakarta: Penerbit Kanisius.

Ife, Jim \& Tesoriero, Frank. 2008. Community Development: Community-Based Altenatives in An Age of Globalisation. Australia: Pearson Education.

Mardikanto,2010. Komunikasi Pembangunan. Acuan bagi Akademisi, Praktisi, dan Peminat Komunikasi Pembangunan. Surakarta: Sebelas Maret University Press.

Miles, M.B. \& Huberman, A.M. 1984. Qualitative Data Analysis: A Sourcebook of New Methods. New York, n.y : Holt, Rinehart, and Winston.

Moleong, Lexy. J. 2004. Metodologi Penelitian Kualitatif. Bandung: Remaja Rosdakarya

Mulyana, Deddy. 2007. Ilmu Komunikasi Suatu Pengantar. Bandung: PT. Remaja Rosdakarya.

Nurudin. 2004. Sistem Komunikasi Indonesia. Jakarta : Rajawali Pers.

Poloma, Margareth. 2004. Sosiologi Kontemporer. Jakarta: Raja Grafindo Persada.

Sulaiman, Adhi Iman. 2013. Model Komunikasi Formal dan Informal dalam Proses Kegiatan Pemberdayaan Masyarakat. Jurnal Penelitian Komunikasi, Volume 16 No.2 Desember 2013, hlm. 173-188.

Sutopo, HB. 2006. Metodologi Penelitian Kualitatif. Dasar Teori dan Terapannya dalam Penelitian. Edisi Kedua. Surakarta: Universitas Sebelas Maret.

Tahoba. 2011. Strategi Komunikasi dalam Program Pengembangan Masyarakat (Community Development), kasus program Community Development pada Komunitas Adat Terkena Dampak Langsung proyek LNG Tangguh di Sekitar Teluk bintuni Kabupaten Teluk Bintuni Papua Barat. Proceeding. http://www.google.com/url?paparisa.unpatti.ac.id, diunduh 21 Januari 2015).

Yin, R.K. 1987. Case Study Research: Design and Methods. Beverly Hills, CA: Sage Publication.

Zubaedi. 2014. Pengembangan Masyarakat. Wacana \& Praktik. Jakarta: Kencana Prenadamedia Group. 